\title{
Design and Analysis of Power Transmission Monopole Using ETABS
}

\author{
T.Subramani $^{*}$, B.Prakash $^{2}$ \\ $1^{*}$ Managing Director, Priyanka Associates (Civil Engineers and Valuers), Salem, TamilNadu, India. \\ ${ }^{2}$ Design Engineer, Anice Rebar ( Civil Engineers and Valuers), Salem, TamilNadu, India. \\ "Corresponding author E-mail: tsmcivil2007@gmail.com
}

\begin{abstract}
Electricity consumption is day by day increase for each and every application. Transmitting the power source from production place to designation place via steel wire is followed by ancient people. In this we use heavy towers which carry minimum of $2000 \mathrm{kw}$ power in each line which is hanged in the towers. These towers are subjected to dynamic and static load cases. Hence in this thesis we proposed to design and analysis the power transmission towers in our places. We introduce type of tower and its configuring ratio as per Indian standard IS-802. A standard kind of transmission line tower selected as case examine is analyzed and modeled the usage of ETABSs software. Loads acting on the tower are wind load, dead load of the structure, braking load of conductor and earthquake load considered as per Indian standard. The place of tower underneath seismic and wind is region III. The wind pressure depends on the gust response component which will increase with height. Seismic and wind analysis is finished the usage of standard codes using ETABSs software program. The conduct of tower is analyzed for distinctive load mixtures. The most displacement values, shear forces and bending moments are obtained and are plotted graphically.
\end{abstract}

Keywords: Design, Analysis, Power Transmission, Monopole and ETABS.

\section{Introduction}

Energy machine stabilizers (EMS) are used as supplementary manipulate devices to provide more damping and improve the dynamic overall performance of the energy machine. EMS are very effective controllers in improving the damping of lowfrequency oscillations because they could increase the damping torque for inter place modes through introducing extra signals into the excitation controllers of the mills. Those oscillations come into lifestyles while mills fall out of step from every different. Depending on their location in the device, a few generators participate in a unmarried mode of oscillation, whereas others take part in a couple of mode. Researchers were putting lots of efforts in the design of most advantageous to meet specific gadget requirements. Numerous design techniques have been suggested. Those algorithms hire big wide variety of particles or individuals in the optimization. Tab is software where we will simulate electricity device components. In this study, the load on time is reduced and the simulation is as quick as feasible. For the metallic plant, first load float evaluation has been executed. The distinctive voltage profile, actual and reactive power injected to the gadget has been determined then quick circuit analysis is carried out for three segment fault and single phase to floor fault, the quick circuit contemporary is cited then transient balance evaluation is noted and the plots have been proven. Herein ETABS, first the unmarried line diagram became drawn. Parameters had been given therefore and cargo drift, brief circuit and temporary stability had been done. in this paper the stairs worried for analysis of steam plant using ETABS modeling is illustrated beneath.

\subsection{Objectives of Our Study}

- To have a look at the analysis and layout of transmission line tower using e tabs software program.

- To study the evaluation of transmission line tower [Single circuit] for numerous loadings (lifeless load or self-weight, seismic load, wind load) appearing on it.

- To obtain displacements, bending moment, shear force, values for analyzed tower.

- To have a look at the member of sections taken into consideration within the evaluation, finding out the best sections for the tower.

- To calculate the wind stress forces performing at the tower, converting into point loads and sporting out wind evaluation.

\subsection{Wireless Transmission}

Power might also be transmitted by changing electromagnetic fields or by radio waves; microwave energy may be carried efficiently over short distances by a waveguide.

\section{Methodology}

Fig. 1 shows the methodology in this study. 


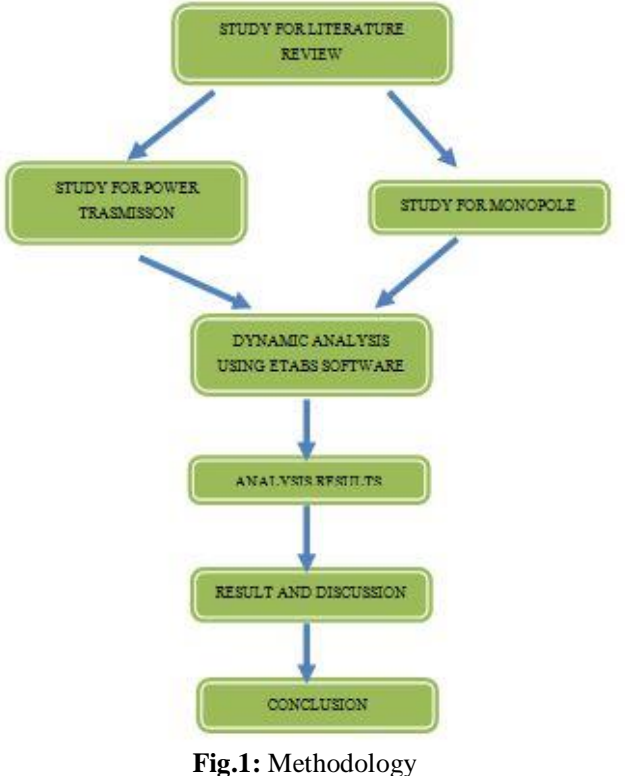

\section{Overhead Transmission}

The present design exercise, towers and conductors are taken into consideration one after the other ignoring the coupling effect and static loads are implemented for my part. Coupled transmission tower-line systems are tremendously complex in their behavior due to the interplay between on-linear conductors and stiff towers which ends up in carefully spaced frequencies. Studied these systems thinking about the geometric non-linearity and aerodynamic damping; however the work became now not in three dimensions. Supplied linear reaction in a coupled gadget the usage of a three-D finite element model. Lately showed that the layout codes overestimate the energy of transmission towers. They added out that a 3-D finite element analysis is greater correct compared to linear evaluation. Until now, not many researchers have studied the coupling impact on reaction of cables using nonlinear dynamic evaluation.

\subsection{Design Tower}

Pulleys that are of various size can be mounted on common shaft in an effort to be connected to motor shaft. Other set of pulleys might be set up on another common shaft. it's far to be noted that as pulleys are of various size, drives may have differential speed and the equal velocity may be conveyed to either side of electromechanical clutch. Without a electrical excitation to the seize, the input shaft $\&$ output shaft freely rotate. With electrical excitation, the enter shaft turns into coupled to the output shaft. Motor feeds the desired torque to force with the intention to be fed to magnetic seize as input whilst the burden torque is less than the output torque, the seize drives without slip. Load torque will be expanded steadily and while it crosses output torque, the clutch will slip easily at the torque stage set through the coil input cutting-edge as enter torque and cargo torque values are acknowledged, cost of load torque at which grasp slips might be taken as output torque. This output torque can be in comparison with enter torque to assess the torque transmitting capacity of the electricity transmission device.

\section{ETABS Application}

\subsection{Description / Main Objectives of Model}

ETABS unsegregated transmission applications were developed for concurrent offline and real-time use. ETABS can combine your load flow, short circuit, dynamic stability, and protection and
SCADA models into one common and unsegregated integrated database. This is the next generation approach as opposed to the current industry practice of trying to couple offline system planning tools with real-time data via external files.

\section{ETABS Results}

\subsection{Wind Load on Panels}

The lateral force due to wind force performing at each panel joint is located as a manufactured from depth of wind and the exposed area of participants of the tower consist of the projected location of the windward pressure plus fifty percent of plant of the leeward force. Fig. 2 suggests the dimensions of tower in meter

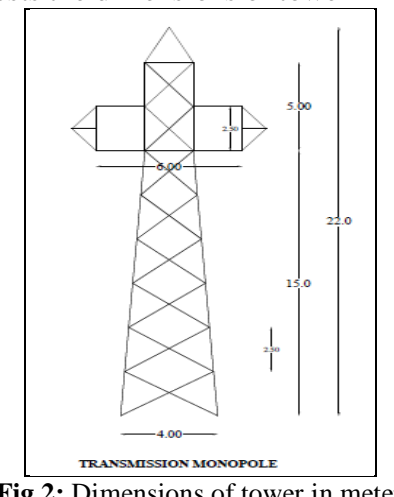

Fig.2: Dimensions of tower in meter

\subsection{ETABS Report}

Fig. 3 shows the tower model in E-tabs

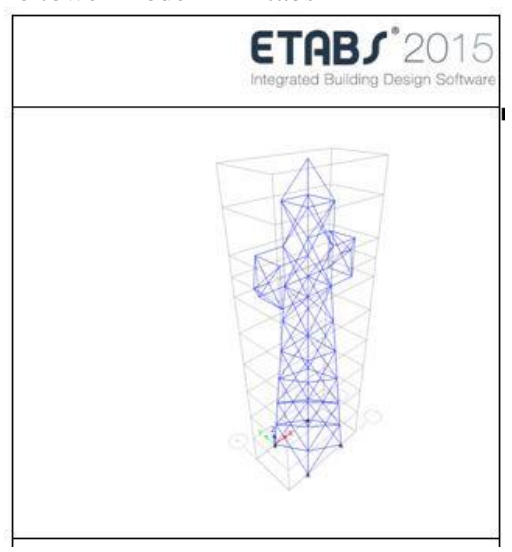

Fig.3: Tower model

\subsubsection{Structure Data}

Table 1 shows the model geometry information, including items such as story levels, point coordinates, and element connectivity.

Table 1: Story Data

\begin{tabular}{|c|c|c|c|c|}
\hline Name & $\begin{array}{c}\text { Height } \\
\mathbf{m m}\end{array}$ & $\begin{array}{c}\text { Elevation } \\
\mathbf{m m}\end{array}$ & Similar To & $\begin{array}{c}\text { Splice } \\
\text { Story }\end{array}$ \\
\hline Story10 & 2000 & 22000 & None & No \\
\hline Story9 & 2500 & 20000 & None & No \\
\hline Story8 & 1250 & 17500 & None & No \\
\hline Story7 & 1250 & 16250 & None & No \\
\hline Story6 & 2500 & 15000 & None & No \\
\hline Story5 & 2500 & 12500 & None & No \\
\hline Story4 & 2500 & 10000 & None & No \\
\hline Story3 & 2500 & 7500 & None & No \\
\hline Story2 & 2500 & 5000 & None & No \\
\hline Story1 & 2500 & 2500 & None & No \\
\hline Base & 0 & 0 & None & No \\
\hline
\end{tabular}




\subsubsection{Properties}

Table 2 and Table 3 show the property information for materials, frame sections, shell sections, and links.

Table 2: Material Properties - Summary

\begin{tabular}{|c|c|c|c|c|c|}
\hline Name & Type & $\begin{array}{c}\mathbf{E} \\
\mathbf{M P a}\end{array}$ & $\mathbf{v}$ & $\begin{array}{c}\text { Unit Weight } \\
\mathbf{k N} / \mathbf{m}^{\mathbf{3}}\end{array}$ & Design Strengths \\
\hline A615Gr60 & Rebar & 199947.98 & 0.3 & 76.9729 & $\begin{array}{c}\mathrm{Fy}=413.69 \mathrm{MPa} \\
\mathrm{Fu}=620.53 \mathrm{MPa}\end{array}$ \\
\hline A992Fy50 & Steel & 199947.98 & 0.3 & 76.9729 & $\begin{array}{c}\mathrm{Fy}=344.74 \mathrm{MPa} \\
\mathrm{Fu}=448.16 \mathrm{MPa}\end{array}$ \\
\hline
\end{tabular}

Table 3: Frame Sections - Summary

\begin{tabular}{|c|c|c|}
\hline Name & Material & Shape \\
\hline DIA & A992Fy50 & Steel Angle \\
\hline HORI & A992Fy50 & Steel Angle \\
\hline MAIN & A992Fy50 & Steel Angle \\
\hline W14X500 & A992Fy50 & Steel I/Wide Flange \\
\hline
\end{tabular}

\subsection{Frame Assignments}

Table 4 shows the frame assignment summary.

Table 4: Frame Assignments - Summary

\begin{tabular}{|l|c|c|c|c|c|c|c|}
\hline Story & Label & $\begin{array}{c}\text { Cuiqu } \\
\text { Name }\end{array}$ & $\begin{array}{c}\text { Design } \\
\text { Type }\end{array}$ & $\begin{array}{c}\text { Lengt } \\
\mathbf{h} \\
\text { mm }\end{array}$ & $\begin{array}{c}\text { Analysis } \\
\text { Section }\end{array}$ & $\begin{array}{c}\text { Design } \\
\text { Section }\end{array}$ & $\begin{array}{c}\text { Min } \\
\text { Number } \\
\text { Stations }\end{array}$ \\
\hline Story9 & C5 & 89 & Column & 2500 & MAIN & MAIN & 3 \\
\hline Story9 & C6 & 90 & Column & 2500 & MAIN & MAIN & 3 \\
\hline Story9 & C7 & 91 & Column & 2500 & MAIN & MAIN & 3 \\
\hline Story9 & C8 & 92 & Column & 2500 & MAIN & MAIN & 3 \\
\hline Story8 & C1 & 5 & Column & 2500 & MAIN & MAIN & 3 \\
\hline Story8 & C2 & 6 & Column & 2500 & MAIN & MAIN & 3 \\
\hline Story8 & C3 & 7 & Column & 2500 & MAIN & MAIN & 3 \\
\hline Story8 & C4 & 8 & Column & 2500 & MAIN & MAIN & 3 \\
\hline Story8 & C9 & 121 & Column & 2500 & W14X500 & W14X500 & 3 \\
\hline Story8 & C10 & 123 & Column & 2500 & MAIN & MAIN & 3 \\
\hline Story8 & C11 & 127 & Column & 2500 & MAIN & MAIN & 3 \\
\hline Story8 & C12 & 128 & Column & 2500 & MAIN & MAIN & 3 \\
\hline Story9 & B1 & 39 & Beam & 2000 & HORI & HORI & \\
\hline Story9 & B2 & 38 & Beam & 2000 & HORI & HORI & \\
\hline Story9 & B3 & 37 & Beam & 2000 & HORI & HORI & \\
\hline Story9 & B4 & 40 & Beam & 2000 & HORI & HORI & \\
\hline Story8 & B5 & 113 & Beam & 2000 & DIA & DIA & \\
\hline Story8 & B6 & 116 & Beam & 2000 & HORI & HORI & \\
\hline Story8 & B7 & 117 & Beam & 2000 & DIA & DIA & \\
\hline Story8 & B8 & 119 & Beam & 2000 & HORI & HORI & \\
\hline
\end{tabular}

\subsection{Loads}

It shows loading information as applied to the model.

\subsubsection{Load Patterns}

Table 5 shows the load patterns

Table 5: Load Patterns

\begin{tabular}{|c|c|c|c|}
\hline Name & Type & $\begin{array}{c}\text { Self Weight } \\
\text { Multiplier }\end{array}$ & Auto Load \\
\hline Dead & Dead & 1 & \\
\hline Live & Live & 0 & \\
\hline W1 & Wind & 1 & Indian IS875:1987 \\
\hline SEI I & Seismic & 1 & IS1893 2002 \\
\hline
\end{tabular}

\subsection{Indian is 875:1987 Auto Wind Load Calculations}

\subsubsection{Exposure Parameters}

Exposure From $\quad=\quad$ Diaphragms

Structure Class $=$ Class B

Terrain Category $=\quad$ Category 2

Wind Direction $\quad=\quad 0.90$ degrees

Table 6 shows the Exposure parameters.

Table 6: Exposure parameters

\begin{tabular}{|c|c|c|c|}
\hline & \multicolumn{2}{|c|}{ 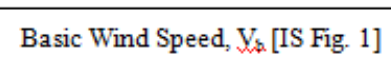 } & $\mathrm{V}_{\mathrm{b}}=50 \frac{\text { meter }}{\mathrm{sec}}$ \\
\hline & \multicolumn{2}{|c|}{ Windward Coefficient, $\mathrm{C}_{\text {proinat }}$} & $\mathrm{C}_{\mathrm{p}, \text { wind }}=0.8$ \\
\hline & \multicolumn{2}{|c|}{ Leeward Coefficient, $\mathrm{C}_{\text {pha }}$} & $C_{p, l e e}=0.5$ \\
\hline Top Stor & & Story10 & \\
\hline Bottom & Story & Base & \\
\hline Include & Parapet & No & \\
\hline
\end{tabular}

\subsubsection{Factors and Coefficients}

Table 7 shows the coefficients.

Table 7: Coefficients

\begin{tabular}{|l|l|}
\hline Risk Coefficient, $\mathrm{k}_{1}$ [IS 5.3.1] & $\mathrm{k}_{1}=1$ \\
\hline Topography Factor, $\mathrm{k}_{3}$ [IS 5.3.3] & $\mathrm{k}_{3}=1$ \\
\hline
\end{tabular}

\subsubsection{Calculated Base Shear}

Table 9 shows the calculated base shear.

Table 8: Calculated base shear

\begin{tabular}{|c|c|c|c|}
\hline Direction & $\begin{array}{c}\text { Period Used } \\
\text { (sec) }\end{array}$ & $\begin{array}{c}\mathrm{W} \\
(\mathrm{kND})\end{array}$ & $\begin{array}{c}\mathrm{V}_{\psi_{k}} \\
(\mathrm{kND})\end{array}$ \\
\hline $\mathrm{X}$ & 0.409 & 621.6055 & 55.9445 \\
\hline $\mathrm{Y}$ & 0.442 & 621.6055 & 55.9445 \\
\hline $\mathrm{X}+\mathrm{E} \rho \mathrm{Y} . \mathrm{Y}$ & 0.409 & 621.6055 & 55.9445 \\
\hline $\mathrm{Y}+\mathrm{E} \rho \mathrm{S} . \mathrm{X}$ & 0.442 & 621.6055 & 55.9445 \\
\hline $\mathrm{X}-\mathrm{E} \rho \mathrm{Y} . \mathrm{Y}$ & 0.409 & 621.6055 & 55.9445 \\
\hline $\mathrm{Y}-\mathrm{Egc} \cdot \mathrm{X}$ & 0.442 & 621.6055 & 55.9445 \\
\hline
\end{tabular}

\section{Conclusion}

This study conclude that dynamic load is more acting compare to the static loading in the tower which has find out and same has been protected from the damage. Structures like angle, box channel etc... has easily designed and analyzed has implemented in the study. Proposed design will enable the designer to recover part of energy required to test the transmission system. In addition the limitations given in different wind design codes in designing power transmission of tower are discussed.

\section{References}

[1]. T.Subramani, J.Jayalakshmi , " Analytical Investigation Of Bonded Glass Fibre Reinforced Polymer Sheets With Reinforced Concrete Beam Using Ansys" , International Journal of Application or Innovation in Engineering \& Management (IJAIEM), Volume 4 , Issue 5, pp. 105-112, 2015

[2]. T.Subramani. , S.Vishnupriya, "Finite Element Analysis of a Natural Fiber (Maize) Composite Beam", International Journal of Modern Engineering Research, Volume. 4, Issue. 6 (Version 1), pp $1-7,2014$, 
[3]. T.Subramani., R.Senthil Kumar, "Modelling and Analysis of Hybrid Composite Joint Using Fem in ANSYS", International Journal of Modern Engineering Research, Volume 4, Issue 6 (Version 1), pp 41- 46, 2014

[4]. T.Subramani, S.Sharmila, "Prediction of Deflection and Stresses of Laminated Composite Plate with Artificial Neural Network Aid", International Journal of Modern Engineering Research, Volume 4, Issue 6 (Version 1), pp $51-58,2014$

[5]. T.Subramani., S.Sundar, M.Senthilkumar, "Investigation of the Behaviour for Reinforced Concrete Beam Using Non Linear Three Dimensional Finite Elements", International Journal of Modern Engineering Research, Volume. 4, Issue. 6 (Version 2), pp 13 -18, 2014 ,

[6]. T.Subramani, A.Arul, "Design And Analysis Of Hybrid Composite Lap Joint Using Fem" International Journal of Engineering Research and Applications, Volume. 4, Issue. 6 (Version 5), pp 289- 295, 2014.

[7]. T.Subramani., J.Jothi,, M.Kavitha "Earthquake Analysis Of Structure By Base Isolation Technique In SAP", International Journal of Engineering Research and Applications, Volume. 4, Issue. 6 (Version 5), pp 296 - 305, 2014.

[8]. T.Subramani., R.Manivannan.R, M.Kavitha, "Crack Identification In Reinforced Concrete Beams Using Ansys Software" ,International Journal of Engineering Research and Applications, Volume. 4, Issue. 6 (Version 6), pp 133 - 141, 2014

[9]. T.Subramani., Reni Kuruvilla, J.Jayalakshmi., "Nonlinear Analysis Of Reinforced Concrete Column With Fiber Reinforced Polymer Bars" International Journal of Engineering Research and Applications Volume. 4, Issue. 6 (Version 5), pp 306- 316, 2014.

[10]. T.Subramani, D.Sakthi Kumar, S.Badrinarayanan. "Fem Modelling And Analysis Of Reinforced Concrete Section With Light Weight Blocks Infill " International Journal of Engineering Research and Applications, Volume. 4, Issue. 6 (Version 6), pp 142 - 149, 2014.

[11]. T.Subramani, B.Saravanan., J.Jayalakshmi., "Dynamic Analysis Of Flanged Shear Wall Using Staad Pro", International Journal of Engineering Research and Applications, Volume. 4, Issue. 6 (Version 6), pp 150 - 155, 2014.

[12]. T.Subramani, M.Subramani., K.Prasath.,"Analysis Of Three Dimensional Horizontal Reinforced Concrete Curved Beam Using Ansys" International Journal of Engineering Research and Applications, Volume. 4, Issue. 6 (Version 6), pp 156 - 161, 2014

[13]. T.Subramani., K.Bharathi Devi., M.S.Saravanan. , Suboth Analysis Of RC Structures Subject To Vibration By Using Ansys," International Journal of Engineering Research and Applications Vol. 4, Issue 12(Version 5), pp.45-54, 2014.

[14]. T.Subramani., K.Bharathi Devi., M.S.Saravanan., Suboth Thomas, "Analysis Of Seismic Performance Of Rock Block Structures With STAAD Pro International Journal of Engineering Research and Applications Vol. 4, Issue 12(Version 5), pp.55- 68, 2014

[15]. T.Subramani., T.Krishnan., M.S.Saravanan.M , Suboth Thomas, "Finite Element Modeling On Behaviour Of Reinforced Concrete Beam Column Joints Retrofitted With CFRP Sheets Using Ansys" International Journal of Engineering Research and Applications Vol. 4, Issue 12(Version 5), pp.69 -76, 2014

[16]. T.Subramani., S.Krishnan., M.S.Saravanan.M, Suboth Thomas "Analysis Of Retrofitting Non-Linear Finite Element Of RCC Beam And Column Using Ansys" International Journal of Engineering Research and Applications ,Vol. 4, Issue 12(Version 5), pp.77-87, 2014

[17]. T.Subramani, J.Jayalakshmi , " Analytical Investigation Of Bonded Glass Fibre Reinforced Polymer Sheets With Reinforced Concrete Beam Using Ansys" , International Journal of Application or Innovation in Engineering \& Management (IJAIEM), Volume 4, Issue 5, pp. 105-112, 2015

[18]. T.Subramani and M.Kavitha, “Analysis Of Reliability Of Steel Frame Systems With Semi-Rigid Connections Using Numerical Method And Finite Element Analysis", International Journal of Applied Engineering Research (IJAER), Volume 10, Number 38,Special Issues, pp.28240-28246, 2015

[19]. T.Subramani, M.S.Saravanan, “Analysis Of Non Linear Reinforced And Post Tensioned Concrete Beams Using ANSYS”, International Journal of Applied Engineering Research (IJAER) International Journal of Applied Engineering Research (IJAER), Volume 10, Number 38 Special Issues, pp.28247-28252, 2015

[20]. T.Subramani, K.Balamurugan , "Finite Element Anaylsis Of Composite Element For FRP Reinforced Concrete Slab By Using ANSYS" , International Journal of Application or Innovation in
Engineering \& Management (IJAIEM), Volume 5, Issue 5, pp. 076-084, 2016.

[21]. T.Subramani, V.Kanian Poonkundran , " Prefabricated Multistory Structure Exposure To Engineering Seismicity By Using SAP" International Journal of Application or Innovation in Engineering \& Management (IJAIEM), Volume 5, Issue 5, pp. 123-131 , 2016.

[22]. T.Subramani, A.Kumaravel , "Analysis Of Polymer Fibre Reinforced Concrete Pavements By Using ANSYS", International Journal of Application or Innovation in Engineering \& Management (IJAIEM), Volume 5, Issue 5, pp. 132-139, 2016

[23]. T.Subramani, R.Praburaj , " Pushover Anaylsis Of Retrofitted Reinforced Concrete Buildings By Using SAP" , International Journal of Application or Innovation in Engineering \& Management (IJAIEM), Volume 5, Issue 5, pp. 140-147 , 2016.

[24]. T.Subramani, M.Senthilkumar , "Finite Element Anaylsis Of RC Beams With Externally Bonded Simcon Laminates By Using ANSYS" , International Journal of Application or Innovation in Engineering \& Management (IJAIEM), Volume 5, Issue 5, pp. $148-155,2016$

[25]. T.Subramani, R.Vasanthi , " Earth Quake Resistant Building Using SAP" , International Journal of Application or Innovation in Engineering \& Management (IJAIEM), Volume 5, Issue 5, pp. $173-181,2016$

[26]. T.Subramani, A.Selvam , " Studies On Economical Configuration Of RCC And Prestressed Shell Roofs By Using ANSYS " International Journal of Application or Innovation in Engineering \& Management (IJAIEM), Volume 5, Issue 5, pp. 182-191, 2016.

[27]. T.Subramani, A.Anbuchezian , "Experimental Investigation On Flexural Behavior Of Folded Ferro Cement Panels " , International Journal of Application or Innovation in Engineering \& Management (IJAIEM), Volume 6, Issue 3, March 2017 , pp. 045 049 , ISSN 2319 - 4847.

[28]. T.Subramani, A. Fizoor Rahman , " An Experimental Study On The Properties Of Pet Fibre Reinforced Concrete " , International Journal of Application or Innovation in Engineering \& Management (IJAIEM), Volume 6, Issue 3, March 2017 , pp. 058066 , ISSN 2319 - 4847.

[29]. T.Subramani, S.Poongothai, S.Priyanka , " Analytical Study Of T Beam Column Joint Using FEM Software " , International Journal of Emerging Trends \& Technology in Computer Science (IJETTCS), Volume 6, Issue 3, May - June 2017 , pp. 148-156 , ISSN 2278-6856

[30]. T.Subramani, R.Ganapathy,V.Manoharan, M.Balamurugan, R.Murugesan , " Design And Analysis Of Light Weight Concrete Building Using ETAB With Respect To Dynamic Loading " International Journal of Emerging Trends \& Technology in Computer Science (IJETTCS), Volume 6, Issue 3, May - June 2017 , pp. 252-258, ISSN 2278-6856.

[31]. T.Subramani, A.Mohammed Ali, R.Karthikeyan, E.Panner Selvan , K.Periyasamy ," Analytical Study Of T-Beam Using ANSYS " , International Journal of Emerging Trends \& Technology in Computer Science (IJETTCS), Volume 6, Issue 3, May - June 2017 , pp. 259-266, ISSN 2278-6856.

[32]. T.Subramani, V.Kalaivanan, S.Priyaranjithkumar, P.Sasikumar, P.Vinoth Kumar, " Design And Analysis Of Multistorey Building With Respect To Seismic Loads Using ETABS " , International Journal of Emerging Trends \& Technology in Computer Science (IJETTCS), Volume 6, Issue 3, May - June 2017, pp. 267-274, ISSN 2278-6856. 